\title{
PERLINDUNGAN HUKUM BAGI KONSUMEN OLEH OTORITAS JASA KEUANGAN (OJK) TERHADAP KEGIATAN INVESTASI ILEGAL YANG DILAKUKAN OLEH INVESTOR
}

\author{
I Gusti Ayu Firga Julia, Ni Luh Made Mahendrawati, Ida Ayu Putu Widiati \\ Fakultas Hukum, Universitas Warmadewa, Denpasar-Bali, Indonesia \\ laksmidewi29@gmail.com
}

\begin{abstract}
Abstrak
Maraknya kasus penipuan dan penawaran investasi yang diduga ilegal mengakibatkan kerugian bagi konsumen dan masyarakat, maka dalam hal ini diperlukannya perlindungan hukum guna meminimalisir terjadi kasus investasi ilegal. Tujuan penelitian ini untuk menganalisa peran otoritas jasa keuangan dalam mengantisipasi kegiatan investasi ilegal yang dilakukan oleh investor serta upaya perlindungan hukum bagi konsumen oleh otoritas jasa keuangan terhadap kegiatan investasi ilegal yang dilakukan oleh investor. Penelitian ini merupakan penelitian yuridis normative dengan pendekatan pendekatan perundang-undangan dan pendekatan konseptual. Teknik pengumpulan bahan-bahan hukum yang digunakan ialah teknik pencatatan. Bahan hukum yang digunakan berupa bahan hukum primer dan sekunder. Setelah data terkumpul selanjutnya data dianalisis secara sistematis. Hasil penelitian mengungkapkan bahwa dalam rangka perlindungan hukum, Otoritas Jasa Keuangan diberikan kewenangan oleh Negara untuk melakukan tindakan pencegahan kerugian konsumen dan masyarakat. Upaya yang dilakukan berdasarkan pada Pasal 28 Undang-Undang No 21 Tahun 2011 Tentang Otoritas Jasa Keuangan dengan melakukan sosialisasi dan edukasi kepada masyarakat mengenai karakteristik kegiatan penghimpunan dana dan pengelolaan investasi ilegal dan meminta Lembaga Jasa Keuangan untuk menghentikan kegiatannya apabila kegiatan tersebut berpotensi merugikan masyarakat. Penanganan yang dilakukan oleh Otoritas Jasa Keuangan ini tidak terlepas dari dukungan masyarakat yang telah menyampaikan laporan atau pengaduan.
\end{abstract}

Kata Kunci: Investasi Ilegal, Jasa Keuangan, Perlindungan Hukum

\begin{abstract}
The rise of fraud cases and investment offers that are suspected to be illegal have resulted in losses for consumers and the public, so in this case legal protection is needed to minimize illegal investment cases. The purpose of this research is to analyze the role of the financial services authority in anticipating illegal investment activities carried out by investors and a legal protection for consumers by the financial services authorities against illegal investment activities carried out by investors. This research is a normative juridical research with a statutory approach and a conceptual approach. The technique of collecting legal materials used is the recording technique. The legal materials used are primary and secondary legal materials. After the data is collected then the data is analyzed systematically. The results of the research reveal that in the context of legal protection, the Financial Services Authority is given the authority by the State to take steps to prevent consumer and public losses. Efforts are made based on Article 28 of Law No. 21 of 2011 concerning the Financial Services Authority by conducting outreach and education to the public regarding the characteristics of fundraising activities and managing illegal investments and asking the Financial Services Institutions to stop their activities if these activities have the potential to harm the community. The handling carried out by the Financial Services Authority cannot be separated from the support of the public who have submitted reports or complaints.
\end{abstract}

Keywords: Illegal Investment, Financial Services Authority, Legal Protection

\section{PENDAhuluan}

Pertambahan keperluan penduduk yang selalu bertambah ialah merupakan efek sebab kesejagatan. Masyarakat sedang giat-giatnya melakukan kegiatan usaha untuk mengembangkan asetnya untuk memohon supaya didapatkannya untuk terpenuhinya keperluan nyawa yang lebih bagus dikemudian hari. Oleh karena itu hukum diperlukan supaya diberikan pembatasan yang sah dan benar berkaitan mengenai apa yang diperbolehkan maupun tidak diperbolehkan mengenai aktivitas bisnis. aktivitas 
bisnis didalam saham pendanaan sangat berselaras dengan akumulasi uang dari penduduk yang dimana tertera di ketentuan perundang-undangan Pasal 16 Undang-undang No. 10 Tahun 1998 mengenai Perbankan. mengenai ketetapan Pasal 16 ayat (1), yang mengandung pengertian bahwasannya aktivitas menyimpan uang dari penduduk kepada semua orang pada awalnya ialah aktivitas yang sangat butuh perhatian, mempertimbangkan mengenai aktivitas yang bersinggunagn kepada keperluan penduduk yang dimana biayanya dijaga oleh kelompok yang menyimpan uang tertera. Berhubungan dalam hal itu mengenai ayat tersebut jelas bahwasannya aktivitas menyimpan uang penduduk dalam desain tabungan hanya bisa dikerjakan dari golongan yang sudah mendapatkan perizinan aktivitas usaha bagaikan bank universal ataupun bagaikan bank perkreditan penduduk (Hermansyah, 2005).

Persetujuan bisnis dengan melahirkan suatu bank yang terbuka dalam ketentuan pasal berikut berganti kewajiban oleh Bank Indonesia kepada Otoritas Jasa Keuangan mengenai ketentuan perundang-undangan Pasal 55 ayat (2) Undang-Undang No. 21 Tahun 2011 mengenai Otoritas Jasa Keuangan mengenai persetujuan mendirikan bank. akumulasi uang oleh penduduk dijaga dengan negara, melalui kewajiban yang dipunyai akibat Otoritas Jasa Keuangan dengan tujuan menjaga keperluan penduduk selaku pelanggan oleh saham pendanaan, pertahanan dikasikan dengan tujuan melindungi segenap penduduk Indonesia oleh bagian-bagian yang bisa membebani penduduk tersebut.

Bagian cara yang mengembang yang terdapat pada usaha oleh bisnis pendanaan ialah cara penanaman modal dengan tujuan prospektif margin yang lumayan besar. Menurut Eduardus Tandelilin Investasi dilakukan dengan harapan memperoleh sejumlah keuntungan dari kenaikan harga saham ataupun sejumlah deviden di masa yang akan datang. Dengan memiliki surplus yang dimana lumayan besar, semakin tumbuh kegiatan penanaman modal di bagian saham pendanaan berikut, sering terdapat penanaman modal yang tidak sah. Dengan tujuan membuktikan pada penduduk, instansi berikut bertugas dengan memiliki tujuan untuk meberitahu bahwa penanaman modal yang digaungkan benar adanya. Namun dalam realitanya, usaha tersebut tidak lain dari hanyalah memutarkan dana yang sudah dihimpun dari konsumen untuk membayarkan keuntungan dan cicilan uang yang sudah diterima dari konsumen baru. Jadi usaha tersebut sangat tergantung kepada akumulasi dana yang masuk melalui konsumen yang baru bukan melalui keuntungan yang diperoleh kegiatan usaha.

Semakin maraknya kegiatan investasi yang dijajakan, disisi lain hal tersebut belum diselaraskan dengan kepedulian penduduk akan banyaknya kegiatan-kegiatan usaha penanaman modal yang belum sah yang menjamur di masyarakat. Praktik investasi ilegal menjanjikan masyarakat mendapatkan keuntungan/bunga tetap pada setiap bulannya. Hal berikut bisa dipahami lewat bentuk usaha penanaman modal yang sangat belum lazim dan bertujuan guna untuk menglewati ketetntuan perbankan didalam menyimpan suatu uang oleh penduduk. Sesuai ketentuan perundang-undangan Pasal 4 Undang-Undang No 21 Tahun 2011 mengenai Otoritas Jasa Keuangan dilahirkannya Otoritas Jasa Keuangan dengan memiliki tujuan supaya kesemua usaha di internal bagian saham pendanaan mampu melindungi kepentingan Konsumen dan masyarakat. Otoritas Jasa Keuangan dibuat untuk mengurangi moral hazard dan mengoptimalkan perlindungan konsumen di sektor jasa keuangan. Maka dengan ini perlu dicermati kewajiban yang dipunyai oleh Otoritas Jasa Keuangan dalam mengalokasikan penjagaan oleh penduduk ataupun pelanggan kepada usaha penanaman modal yang tidak sah yang dilakukan oleh investor.

Salah satu aspek atau pertimbangan dibentuknya suatu otoritas jasa keuangan sebagai regulator dan pengawas industri jasa keuangan yang terintegrasi di Indonesia adalah untuk melindungi hak dan kepentingan pihak yang berstatus sebagai konsumen dalam industri jasa keuangan (Dimyati, 2014). Otoritas Jasa Keuangan sebagai lembaga yang independen yang mempunyai fungsi, tugas, dan wewenang pengaturan, pengawasan, pemeriksaan, dan penyidikan mempunyai peranan yang penting dalam penanganan kasus dugaan investasi Ilegal yang sedang berkembang saat ini di Indonesia (Ahmad, 2018). Menurut Fadlia \& Yunanto (2015) terdapat 2 (dua) peran OJK dalam perlindungan hukum bagi investor atas dugaan investasi fiktif, yaitu melalui tindakan preventif dan represif. Tindakan contohnya melakukan sosialisasi dan edukasi kepada masyarakat mengenai karakteristik kegiatan penghimpunan dana dan pengelolaan investasi, pemberian izin usaha oleh otoritas terhadap pihak yang menghimpun dana masyarakat, mengoptimalkan fungsi Layanan Keuangan Terintegrasi atau ntegrated Financial Customer Care (IFCC), OJK mengeluarkan aturan pelaksanaan penawaran 
produk dan/atau layanan jasa keuangan, dan peningkatan literasi keuangan masyarakat. Sedangkan tindakan represif seperti pembentukan Satuan Tugas (Satgas) Waspada Investasi, OJK membentuk Investor Protection Fund (IPF), OJK menerbitkan Peraturan Otoritas Jasa Keuangan Nomor 1/POJK.07/2013 tentang Perlindungan Konsumen Sektor Jasa Keuangan, dan penyelesaian sengketa di sektor jasa keuangan yang terdiri dari pelaksanaan Internal Dispute Resolution oleh lembaga jasa keuangan dan pelaksanaan External Dispute Resolution di sektor jasa keuangan.

Berdasarkan uraian diatas, maka tujuan penelitian ini guna untuk menganalisa peran otoritas jasa keuangan dalam mengantisipasi kegiatan investasi ilegal yang dilakukan oleh investor serta upaya perlindungan hukum bagi konsumen oleh otoritas jasa keuangan terhadap kegiatan investasi ilegal yang dilakukan oleh investor.

\section{METODE PENELITIAN}

Jenis penelitian ini adalah penelitian hukum yuridis normatif (normative legal reserch) yaitu penelitian yang dilakukan dengan cara melakukan studi kepustakaan dengan mengkaji perundangundangan yang berlaku serta bahan-bahan hukum lainnya dan diterapkan terhadap suatu permasalahan hukum tertentu (Soejono \& Abdurrahman, 2003). Sedangkan pendekatan masalah yang digunakan adalah pendekatan perundang-undangan dan pendekatan konseptual. Bahan hukum yang digunakan dalam penelitian ini meliputi bahan hukum primer dan bahan hukum sekunder. Teknik pengumpulan bahan-bahan hukum yang digunakan ialah teknik pencatatan yaitu dengan membaca, mencatat, mengutip, meringkas, dan mengulas informasi data-data dari peraturan perundang-undangan maupun literatur-literatur yang tentunya berkaitan dengan permasalahan. Dengan mencari bahan dalam bukubuku terkait perlindungan hukum bagi konsumen oleh Otoritas Jasa Keuangan (OJK) dalam usaha penanaman modal yang tidak sah yang digunakan oleh pelanggan. Setelah data dikumpulkan maka data dianalisis secara sistematis.

\section{HASIL DAN PEMBAHASAN}

\section{Peran Otoritas Jasa Keuangan dalam Mengantisipasi Kegiatan Investasi Ilegal yang dilakukan oleh Investor}

Penanaman modal ialah kewajiban atas semua uang ataupun berbagai basis usaha yang lainnya yang dikerjakan sekarang juga, mempunyai maksud untuk mendapatkan laba di masa yang akan datang (Tandelilin, 2010). Penjelasan mengenai Otoritas Jasa Keuangan (OJK) bisa dicermati dibagian Pasal 1 Undang-Undang Nomor 21 Tahun 2011 mengenai Otoritas Jasa Keuangan melafalkan bahwasannya Otoritas Jasa Keuangan, yang disederhanakan menjadi OJK, ialah merupakan institusi yang netral dan lepas atas campur tangan golongan yang berlainan, yang memiliki manfaat, tanggungjawab, dan kedaulatan kontrol, penjagaan, investigasi, dan peneylidikan yang dimana dijelaskan pada UndangUndang ini.

Mengenai agenda perundang-undangan mengani Otoritas Jasa Keuangan. sebagai normatif maksud mendirikan Otoritas Jasa Keuangan tentu bagus. Yang pertama, memajukan dan memiliki keyakinan rakyat di bagian jasa pendanaan. Kedua, meneguhkan aturan undang-undang di bagian jasa pendanaan. Ketiga, memajukan pengertian penduduk dalam bidang jasa pendanaan. Keempat, mempertahankan keinginan pelanggan jasa pendanaan (Sutedi, 2014).

Bertambahnya mata pencaharian penduduk tahun demi tahun menjadikan makin banyak jenis barang pendanaan yang dijajakan di Indonesia. Melonjaknya pendapatan pendanaan itu mengakibatkan kualitas beli penduduk tentunya yang berkarakter royal atapun penanaman modal, tentunya penduduk acapkali sekadar melihat tingginya balasan hasil yang dijajakan oleh sebab janjijanji hasil penanaman modal. suasana tersebut yang membuat menyebabkan sering terjadinya persoalan pembohongan dan menjajakan penanaman modal yang dianggap haram oleh penduduk. Oleh sebab itu, tentunya harus waspada dan cermat didalam melakukan penanaman modal supaya tidak kecewa di masa depan. Untuk itu, perlu dilihat apa saja peran Otoritas Jasa Keuangan (OJK) dalam hal mengantisipasi kegiatan investasi ilegal yang dilakukan oleh investor:

1) Membuat Investor Alert Portal

Otoritas Jasa Keuangan (OJK) membuat Investor Alert Portal atau portal website berisi perusahaan investasi keuangan yang tidak terdaftar di Otoritas Jasa Keuangan (OJK). Investor Alert Portal dibuat sebagai respon atas pertanyaan dari masyarakat melalui Layanan Konsumen OJK terhadap legalitas entitas yang menawarkan investasi. Dibuatnya Investor Alert Portal ini merupakan salah satu upaya 
Otoritas Jasa Keuangan (OJK) selama mencegah banyaknya penanaman modal yang haram yang terjadi di Indonesia. maksud dibentuknya website ini ialah guna menambahkan pemahaman penduduk didalam menjalani usaha penanaman modal, maka kehilangan yang diperoleh dari usaha penanaman modal yang tidak sah keabsahannya dapat dilawan. Tetapi, penduduk harus diberikan pemahaman untuk melaksanakan pemeriksaan kembali pada otoritas yang berkaitan lainnya contohnya yaitu Bappebti (Badan Pengawas Perdagangan Berjangka Komoditi), Badan Koordinasi Penanaman Modal (BKPM), ataupun Kemenkop-UKM bagaikan pembenaran akan substansi yang dimana namanya belum terdaftar tersebut. Investor Alert Portal ini dapat diakses melalui alamat portal https://sikapiuangmu.ojk.go.id/FrontEnd/AlertPortal/Home. Masyarakat juga diharapkan dapat berpartisipasi dalam menyampaikan informasi berkaitan mengenai penjajakan penanaman modal yang disangka diragukan dengan pelayanan pelanggan OJK 157, email konsumen@ojk.go.id atau waspadainvestasi@ojk.go.id.

2) Memastikan pemberian izin usaha oleh otoritas terhadap pihak yang menghimpun dana masyarakat.

Usaha jam kerja badan, industri, serta rakyat individu yang bertentangan dengan hukum didalam menyimpan uang dari penduduk serta penyelenggaraan penanaman modal secara tidak sah tidak dipenuhi dengan arsip pengesahan yang legal. penduduk diberikan pemahaman supaya tidak melaksanakan penanaman modal kepada substansi yang belum sah keabsahannya maupun penjagaannya. Oleh sebab itu, masyarakat diharapkan untuk memastikan terlebih dahulu bahwasannya rakyat atau industri yang telah melaksanakan penjajakan penanaman modal yang sudah mengantongi pengesahan yang legal selaras dengan tujuaannya kepada salah satu intitusi yang berhak, contohnya yaitu : Bank Indonesia, Otoritas Jasa Keuangan, maupun Bappebti (Badan Pengawas Perdagangan Berjangka Komoditi), serta Kementerian Koperasi dan UKM terlebih dahulu untuk ikut dan atau melakukan kegiatan penanaman modal.

3) Pembentukan Satuan Tugas (Satgas) Waspada Investasi

Berdasarkan Surat Keputusan Ketua Badan Pengawas Pasar Modal dan Lembaga Keuangan (Bapepam-LK) Nomor: Kep- 208/BL/2007 yang ditetapkan pada tanggal 20 Juni 2007 untuk masa kerja tahun 2007 dimana diubah menjadi baru pada setiap tahunnya. Selanjutnya sehabis dialihkannya wewenang dan tujuan Bapepam-LK menjadi Otoritas Jasa Keuangan (OJK), Surat Keputusan Satgas Waspada Investasi tersebut diperbarui melalui Keputusan Dewan Komisioner OJK Nomor: 01/KDK.04/2013 tanggal 26 Juni 2013, dibentuk Satgas penindakan Dugaan Tindakan Melawan Hukum di Bidang penyimpanan uang penduduk serta Pengelolaan penanaman modal. Satgas ini ialah buah kolaborasi Otoritas Jasa Keuangan (OJK) bersamaan dengan Kementerian Perdagangan, Kementerian Komunikasi dan Informatika, Kemeterian Koperasi dan Usaha Kecil dan Menengah, Kejaksaan, Kepolisian RI, dan Badan Koordinasi Penanaman Modal (BKPM) guna menindak dan menangani masifnya penjajakan dan usaha penanaman modal yang tidak sah. (Tongam L. Tobing, 2016).

\section{Upaya Perlindungan Hukum bagi Konsumen oleh Otoritas Jasa Keuangan terhadap Kegiatan Investasi Ilegal yang dilakukan Oleh Investor}

Investasi ilegal merupakan suatu investasi yang tidak wajar dan berupaya untuk menghindari aturan perbankan dalam menghimpun dana dari masyarakat dalam bentuk simpanan. Investasi ilegal pada umumnya menggunakan money game ataupun rancangan Ponzi, yaitu memaikan uang pelanggan beserta melunasi hadiah pelanggan lama beserta aliran dana dari pelanggan yang baru (Widayati, 2013).

Pada khususnya penanaman modal yang tidak sah dapat diketahui dapat dengan belum mempunyai arsip pengesahan yang legal dari pihak pengawas yang melekat contohnya Otoritas Jasa Keuangan, Bank Indonesia, Badan Pengawas Perdagangan Berjangka Komoditi (Bappebti)Kementerian Perdagangan, Kementerian Koperasi dan UKM, dan yang lain-lainnya. Oleh karena itu, Otoritas Jasa Keuangan bekerja sama dengan instansi pendanaan harus memberikan pemahaman lebih pada penduduk supaya mengetahui model dan metode penanaman modal yang tidak sah. Sikap konsumtif masyarakat Indonesia membuat disebabkannya banyak usaha penjajakan penanaman modal yang tidak sah, hal tersebut menyebabkan kerugian bagi masyarakat yang telah menanamkan uangnya. Maka dari itu diperlukan adanya perlindungan hukum bagi konsumen untuk mencegah terjadinya kerugian dan memberikan rasa aman kepada masyarakat yang ingin melakukan investasi. 
Perlindungan hukum adalah berbagai macam upaya hukum yang diberikan oleh aparat penegak hukum untuk memberikan rasa aman, baik secara pikiran maupun fisik dari gangguan dan berbagai macam ancaman dari pihak manapun. Oleh karena itu, Otoritas Jasa Keuangan dipersilakan mrmpunyai tugas dengan tujuan mengabulkan kegiatan penanggulangan kehilangan uang pelanggan dan penduduk menganai usaha penanaman modal yang tidak sah yang dikerjakan oleh pemodal (Kansil, 1989).

Untuk itu, perlu dilihat cara yang dilakukan dalam membentengi hukum kepada pelanggan dari Otoritas Jasa Keuangan (OJK) kepada usaha penanaman modal yang tidak sah yang dimana dibuat dari pelanggan:

1) Melakukan peningkatan dalam menyampaikan informasi dan edukasi kepada masyarakat mengenai karakteristik kegiatan penghimpunan dana dan pengelolaan investasi ilegal

Langkah ini merupakan upaya Otoritas Jasa Keuangan dalam rangka menjalankan amanat Pasal 28 huruf a Undang-Undang Nomor 21 Tahun 2011 tentang Otoritas Jasa Keuangan yaitu memberikan informasi dan edukasi kepada masyarakat mengenai karakteristik sektor jasa keuangan, layanan, dan produknya. Dengan pemberian informasi dan edukasi mengenai keunikan usaha penyimpanan uang dan pengendalian penanaman modal yang tidak sah, penduduk diwajibkan mampu lolos serta tidak gampang terangsang melakukan penanaman modal terhadap institusi yang belum sah tatanan serta kebenaran keabsahannya.

Masyarakat harus mengetahui tahu terlebih dahulu model investasi yang ditawarkan oleh perusahaan sebelum memutuskan untuk melakukan investasi agar terhindar dari investasi ilegal. Karena saat ini banyak masih masyarakat yang hanya mementingkan imbal hasil yang ditawarkan tanpa mengetahui kejelasan model investasi yang dijalaninya, hal ini yang nantinya berujung kerugian atas dana yang telah ditanamkan dalam kegiatan investasi tersebut. Selain itu, Otoritas Jasa Keuangan memberikan informasi kepada masyarakat dengan mengklarifikasi legalitas atas tawaran investasi yang diduga ilegal berdasarkan pengaduan masyarakat melalui Layanan Konsumen Otoritas Jasa Keuangan (OJK), yang nantinya akan disampaikan melalui Investor Alert Portal (IAP). Informasi yang terdapat dalam Investor Alert Portal (IAP) tersebut berdasarkan atas pertanyaan dari masyarakat terkait legalitas entitas yang menawarkan investasi melalui Layanan Konsumen OJK 157, email konsumen@ojk.go.id atau waspadainvestasi@ojk.go.id.

2) Melalukan tindakan penghentian kegiatan penghimpunan dana masyarakat dan pengelolaan investasi ilegal

Sesuai ketentuan peraturan perundang-undangan Pasal 28 huruf b dan c Undang-Undang Nomor 21 Tahun 2011 dalam hal Otoritas Jasa Keuangan, Otoritas Jasa Keuangan mempunyai tugas untuk menagih institusi jasa pendaan untuk memberhentikan usahanya jika usaha itu mempunyai energi untuk membebani penduduk serta berbuat kegiatan yang lain yang disangka harus selaras bersama dengan peraturan perundang-undangan oleh usaha saham pendanaan. SatGas Waspada Investasi berwenang melaporkan suatu institusi yang dimana sebagai isntitusi pemodal yang tidak jelas maupun memiliki kewenangan untuk menstop kegiatan usahanya disebabkan dicurigai melakukan suatu kegiatan dengan tidak memiliki keselarasan dari lingkungan yang berhak dan memiliki potensi memberatkan penduduk guna menganugerahkan pemeliharaan hukum pada penduduk, tentunya pelanggang di bidang jasa keuangan. Sebelum memberhentikan industri penanaman modal yang tidak sah, Otoritas Jasa Keuangan (OJK) maupun SatGas Waspada Investasi berhak melaksanakan kegiatan peninjauan maupun penyelidikan mengenai industri pemodalan yang dicurigai belum sah sesuai berita yang disiarkan oleh industri pemodalan tersebut melalui berbagai media sosial baik cetak maupun elektronik dan selanjutnya menyatakan perusahaan tersebut harus menghentikan kegiatan usahanya apabila melanggar aturan hukum yang berlaku.

\section{SIMPULAN DAN SARAN}

\section{Simpulan}

Meningkatnya pemasukan penduduk disebabkan membuat banyaknya jenis komoditas pendanaan yang dijajakan di Indonesia. Salah satunya contohnya yaitu penanaman modal, persoalannya penduduk sekadar melihat tingginya imbal hasil yang dijajakan dikarenakan janji-janji hasil penanaman modal. keadaan ini yang menyebabkan membuat penyebab makin banyaknya masalah 
pembohongan maupun penjajakan penanaman modal yang dianggap tidak sah oleh penduduk. Oleh sebab itu, Otoritas Jasa Keuangan diperbolehkan memiliki tugas dan tanggung jawab lebih oleh Negara untuk menyelenggarakan upaya penanggulangan kehilangan uang pelanggan maupun penduduk. Pertama, membuat Investor Alert Portal. Kedua, memastikan dalam mengalokasikan suatu persetujuan bisnis kepada otoritas orang yang akan menyimpan uang penduduk. Ketiga, dengan pembentukan Satuan Tugas (Satgas) Waspada Investasi. Hal ini diharapkan dapat mengantisipasi kegiatan penanaman modal yang belum sah yang digaungkan bagi pemodal. Bahwa Otoritas Jasa Keuangan diperbolehkan untuk mempunyai tugas dan tanggungjawab untuk mempersembahkan bantuan hukum oleh pelanggan terhadap usaha penanaman modal yang tidak sah yang digaungkan oleh pemodal sesuai ketentuan pada Pasal 28 huruf a Undang-Undang No. 21 Tahun 2011 Tentang Otoritas Jasa Keuangan yang bersifat preventif (pencegahan) dengan melakukan peningkatan dalam menyampaikan informasi dan bimbingan untuk penduduk dalam hal kualitas suatu usaha untuk menyimpan uang dan penataan penanaman modal yang belum sah dan sesuai ketentuan peraturan perundang-undangan pada Pasal 28 huruf b dan c Undang-Undang No. 21 Tahun 2011 Tentang Otoritas Jasa Keuangan memiliki sifat represif bersama mensyaratkan institusi Jasa Keuangan untuk memberhentikan usahanya jika usaha itu memiliki potensi memebratkan penduduk maupun menyelenggarakan kegiatan yang lain yang disangka mendesak yang selaras dengan norma perundang-undangan yang berlaku di sektor jasa keuangan.

\section{Saran}

Maka berdasarkan simpulan diatas, saran yang dapat penulis sampaikan adalah tugas bersama penduduk sangat perlu difungsikan, terpenting supaya tidak dijadikan anggota usaha substansi yang dijajakan pada penanaman modal yang belum sah dan secepatnya memberitahu apabila terjadi penjajakan suatu penanaman modal yang belum sah atau diluar nalar. penindakan yang diperbuat untuk Otoritas Jasa Keuangan dalam usaha menjaga pelanggan tersebut supaya tidak terjatuh dari sokongan penduduk yang sudah dijelaskan dalam aduan ataupun tuduhan. Dengan berikut, penanaman modal yang belum sah tersebut tidak akan bisa mengembang dan meberatkan lebih banyak pelanggan.

\section{DAFTAR PUSTAKA}

Ahmad, S. D. (2018). Peranan Otoritas Jasa Keuangan dalam Penanggulangan Investasi Ilegal di Indonesia. Jurnal Privat Law, 6(1), 1-12.

Dimyati, H. H. (2014). Perlindungan Hukum bagi Investor dalam Pasar Modal. Jurnal Cita Hukum, $1(2), 341-356$.

Fadlia, D. H., \& Yunanto. (2015). Peran Otoritas Jasa Keuangan (OJK) dalam Perlindungan Hukum bagi Investor atas Dugaan Investasi Fiktif. Jurnal Law Reform, 11(2), 207-215.

Hermansyah. (2005). Hukum Perbankan Nasional Indonesia. Kencana Prenada Media Group, Jakarta. Kansil, C. (1989). Pengantar Ilmu Hukum dan Tata Hukum Indonesia. Balai Pustaka, Jakarta.

Soejono, \& Abdurrahman, H. (2003). Metode Penelitian Hukum. Rineka Cipta, Jakarta.

Sutedi, A. (2014). Aspek Hukum Otoritas Jasa Keuangan. Raih Asa Sukses, Jakarta.

Tandelilin, E. (2010). Portofolio dan Investasi. Kanisius, Yogyakarta.

Tobing, T. L. (2020). Siaran Pers OJK Perkuat Satgas Waspada Investasi. Otoritas Jasa Keuangan.

Widayati, L. S. (2013). Pencegahan dan Penanganan Investasi Ilegal. Info Hukum. Pusat Pengkajian Pengolahan Data Dan Informasi (P3DI) Sekretariat Jenderal DPR RI., Vol. 5. 